навчання $€$ формування i розвиток комунікативної компетенції, тобто готовність i здатність студента до мовного спілкування.

У сучасних мінливих умовах розвитку світового ринку якість підготовки молодих фахівців не завжди відповідає очікуванням роботодавців. Компетентнісний підхід покликаний розв'язати цю суперечність між вимогами до сучасного кваліфікованого фахівця і реальною підготовкою у виші. Упровадження до системи освіти компетентнісного підходу дозволить реалізувати розроблені раніше підходи в освітньому процесі, оскільки виокремлення компетенцій у змісті навчальних курсів дозволяє відібрати ті знання, уміння і навички, які найбільш значимі для формування ціннісних орієнтацій.

Компетентнісний підхід, як слушно зазначає І. Зимня, дозволить посилити практикоорієнтованість освіти, іiі предметно-професійний аспект, підкреслює роль досвіду, вмінь практично реалізувати знання, розв'язувати завдання [3].

Як підкреслюється дослідниками, які плідно працюють в окресленому напрямі, компетентнісний підхід, ключові компетенції становлять діяльнісні характеристики майбутнього фахівця, вивляються в умінні мобілізувати отримані знання i досвід, розв'язувати проблеми, в умінні проектувати свої дії. Це означає оволодіння знаннями, уміннями і навичками через діяльність і в діяльності.

Вимога сучасного суспільства до випускника ВНЗ, його професійних особистісних якостей відбивається також у вимогах до володіння іноземною мовою, які визначають кінцеві цілі іншомовної підготовки.

Прийнято виокремлювати стратегічний, тактичний і оперативний рівні цілей навчання. Стратегічна мета визначається як провідна, оскільки спрямована на формування ключових компетенцій, що відображає потребу суспільства в оволодінні іноземною мовою як засобом розвитку особистості, його професійних й особистісних якостей. За допомогою компетенцій студенти опановують функціональною грамотністю, що забезпечує ефективне виконання професійних функцій із використанням іноземної мови. Компетентнісний підхід у проектуванні цілей навчання іноземних мов забезпечує більш якісну підготовку до реального професійного життя, передбачаючи знання предмета й реалізацію своїх особистісних ресурсів.

\title{
Література
}

1. Новиков А. М. Образовательный проект (методология образовательной деятельности) / А. М. Новиков, Д. А. Новиков. - М. : Эгвес, 2004. - 120 с. 2. Равен Дж. Компетентность в современном обществе: явление, развитие и реализация / Дж. Равен ; [пер. 3 англ.]. - М. : КогитоЦентр, 2002. - 396 с. 3. Зимняя И. А. Компетентность человека - новое качество результата образования / И. А. Зимняя // Проблемы качества образования. - Кн. 1. Актуальные задачи обновления и развитие образовательных стандартов. - М., 2003. - 66 с.

УДК 37.091.2-057.87:03

В. В. Кирикилиця, аспірант, Східноєвропейський нащіональний університет імені Лесі Украӥнки

\section{ЕКСПЕРИМЕНТАЛЬНЕ ДОСЛІДЖЕННЯ АКТИВІЗАЦІЇ НАВЧАЛЬНО-ПІЗНАВАЛЬНОЇ ДІЯЛЬНОСТІ СТУДЕНТІВ У ПРОЦЕСІ РОБОТИ ЗІ СЛОВНИКАМИ}

Кирикилиця В. В. Екпериментальне дослідження активізації навчально-пізнавальної діяльності студентів у процесі роботи зі словниками.

У статті на основі аналізу результатів експериментального дослідження визначено рівні сформованості критеріїв активізації навчально-пізнавальної діяльності студентів у процесі роботи зі словниками.

Ключові слова: навчально-пізнавальна діяльність, критерії активізації, показники, рівні сформованості, дослідження, робота зі словниками. 
Кирикилица В. В. Экспериментальное исследование активизации учебно-познавательной деятельности студентов в процессе работы со словарями.

В статье в результате проведенного анализа данных экспериментального исследования определены уровни сформированности критериев активизации учебно-познавательной деятельности студентов в процессе работы со словарями.

Ключевые слова: учебно-познавательная деятельность, критерии активизации, показатели, уровни сформированности, исследование, работа со словарями.

Kyrykylytsia V. V. Experimental research of activation of students' knowledge and cognitive activity in the process of working with dictionaries.

In the article levels of criteria formation of students' knowledge and cognitive activities activation in the process of working with dictionaries are defined on the basis of the experimental research analysis.

Key words: knowledge and cognitive activity, criteria activation, indices, levels of formation, research, dictionaries activity.

Проблема активізації навчально-пізнавальної діяльності студентів належить до найбільш актуальних у сучасній педагогічній теорії і практиці. Активізація навчально-пізнавальної діяльності студентів є однією з умов професійної підготовки майбутнього фахівця у ВНЗ. Метод активізації забезпечує інтенсивне навчання, під час якого навчальні цілі досягаються за мінімальний термін за максимального обсягу необхідного навчального матеріалу [2, с. 42-47].

Цілком очевидно, що розв'язання проблеми активізації навчально-пізнавальної діяльності студентів немовних спеціальностей потребує нових підходів до подальшого вдосконалення змісту навчання, його форм, методів та засобів, які спрямовують студента на удосконалення вже отриманих і пошук нових знань.

У вітчизняній педагогічній літературі проблемі активізації процесу навчання присвячено багато робіт. На всіх етапах розвитку педагогічної думки вона була в полі зору багатьох науковців, педагогів-практиків. Психологічний аспект досліджуваної проблеми висвітлений у працях Б. Ананьєва, Л. Виготського, П. Гальперіна, В. Давидова, Д. Ельконіна, О. Леонтьєва, С. Рубінштейна, Н. Тализіної. Значний внесок в розкриття цієї проблеми здійснили такі педагоги, як Ю. Бабанський, М. Данилов, Б. Ссипов, І. Лернер, В. Лозова, М. Махмутов, Р. Нізамов, М. Скаткін, І. Харламов, Т. Шамова, В. Шморгун, Г. Щукіна. Проблему активізації пізнавальної діяльності студентів на рівні дисертаційних досліджень вивчали В. Гапонова, І. Куліш, О. Олексюк, С. Семеріков, Т. Сердюк, О. Собаєва.

Однак, слід зауважити, що питання дослідження рівнів сформованості критеріїв активізації навчально-пізнавальної діяльності студентів немовних спеціальностей у процесі роботи зі словниками ще не розглядалося.

Метою статті є визначення рівнів сформованості критеріїв активізації навчальнопізнавальної діяльності студентів немовних спеціальностей у процесі роботи зі словниками на констатувальному етапі експериментального дослідження.

Експериментальне дослідження активізації навчально-пізнавальної діяльності студентів у процесі роботи зі словниками було здійснено на базі факультетів немовних спеціальностей Волинського національного університету імені Лесі Українки. Дослідноекспериментальна робота проходила протягом 6 років, 32007 по 2012 рр., і стала продовженням дослідної роботи, здійснюваної автором протягом багатьох років викладання іноземної мови.

У педагогічному експерименті взяли участь 322 студенти I-IV курсів немовних спеціальностей, 3-поміж яких 160 студентів експериментальних та 162 студенти контрольних груп, а також 24 викладачі.

Для аналізу отриманих результатів було створено програму діагностування вияву таких критеріїв активізації навчально-пізнавальної діяльності студентів у процесі роботи зі словниками: мотиви навчання іноземної мови 3 використанням словників; оперування вміннями та навичками роботи зі словником; якість роботи, виконаної зі словником; 
пізнавальна активність у процесі роботи зі словником; пізнавальна самостійність у процесі роботи зі словником; готовність до використання словника для самоосвіти; готовність до використання словника у професійній діяльності.

Одним із завдань дослідження було з'ясувати наявний рівень мотивів навчання іноземних мов 3 використанням словників, оскільки мотив $є$ внутрішньою рушійною силою, що спонукає особистість до діяльності [3].

За показником пізнавального інтересу студентів до виконання різних видів робіт зі словником та періодичності їх проведення було виявлено рівні розвитку мотивів навчання іноземної мови з використанням словника в контрольних та експериментальних групах (табл. 1).

Таблиия 1

Рівні розвитку мотивів навчання іноземної мови з використанням словника

\begin{tabular}{|c|c|c|}
\hline \multirow{2}{*}{ Рівні } & \multicolumn{2}{|c|}{ Студенти (\%) } \\
\cline { 2 - 3 } & Контрольна група & Експеримент. Група \\
\hline високий & 15,5 & 14,9 \\
\hline середній & 26,8 & 27,1 \\
\hline низький & 57.7 & 58 \\
\hline
\end{tabular}

Проаналізувавши таблицю 1, робимо висновок, що у студентів контрольної й експериментальної групи переважає низький і середній рівень мотивів навчання іноземної мови 3 використанням словника. На нашу думку, це пояснюється відсутністю або недостатнім рівнем умінь і навичок користування словником, а в окремих випадках недостатнім забезпеченням студентів словниками.

Немає сумніву, що критерій сформованості мотивів навчання іноземної мови 3 використанням словника прямо впливає на розвиток інших критеріїв активізації навчально-пізнавальної діяльності студентів і має вирішальне значення серед інших критеріїв.

Одним із найдієвіших критеріїв активізації навчально-пізнавальної діяльності студентів у процесі роботи зі словником є оперування вміннями і навичками такої роботи. Рівні оперування вміннями та навичками роботи зі словником оцінювалися за показниками знання студентами алфавіту, структури словника, швидкості пошуку слів у словнику, відбору і запису інформації про нове слово у свій словник та кількості правильно перекладених слів під час написання словникового диктанту. Продемонструємо це наочно за допомогою ілюстративної діаграми (див. рис. 1).

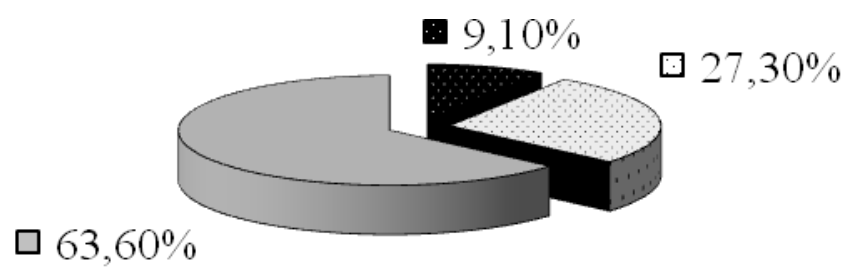

Високий $\square$ Середній 口Низький

Рис. 1. Рівні оперування вміннями та навичками роботи зі словником

Аналізуючи діаграму, можна зробити висновок, що більшість студентів контрольної та експериментальної групи володіє вміннями та навичками роботи зі словником на низькому $(63,6 \%)$ і середньому $(27,3 \%)$ рівнях. Причиною цього є недостатнє знання студентами самого словника: його суті, будови і характеристики властивих йому ознак.

Оскільки будь-яка діяльність породжується потребами і мотивами, то головним мотивом студентів повинно бути одержання глибоких і міцних знань у процесі роботи зі словниками. 
На заняттях 3 іноземної мови для немовних спеціальностей передовсім передбачається здобуття не так теоретичних знань про словник, як практичних умінь та навичок застосування словника для вивченого мовного матеріалу.

Перевірка якості виконаної роботи зі словником передбачала перевірку сформованості фонетичних, лексичних і граматичних мовленнєвих навичок (мовна компетенція), які $є$ складовими компонентами мовленнєвих умінь (мовленнєва компетенція) - говоріння, читання, аудіювання і письма [4].

На основі проведеної контрольної роботи ми визначили рівні якості виконання роботи зі словником за кількістю отриманих відповідей: правильних повних, правильних неповних, неправильних. Правильність виконання завдань оцінювалася за показниками точності, повноти, глибини, усвідомленості та об'ємності. Результати дослідження рівня якості виконання роботи зі словником наведено в табл. 2.

Таблиия 2

Рівні якості виконання роботи зі словником

\begin{tabular}{|c|c|c|}
\hline \multirow{2}{*}{ Рівні } & \multicolumn{2}{|c|}{ Студенти (\%) } \\
\cline { 2 - 3 } & Контрольна група & Експеримент. група \\
\hline високий & 14,2 & 14,5 \\
\hline середній & 58,5 & 57,8 \\
\hline низький & 27,3 & 27,7 \\
\hline
\end{tabular}

3 таблиці 2 видно, що високий рівень якості виконання роботи зі словником мають лише 14,2 \% студентів контрольної і 14,5 \% студентів експериментальної груп. Середній рівень характерний для $58,5 \%$ студентів контрольної групи і $57,8 \%$ студентів експериментальної групи, а низький - для 27,3 \% студентів контрольної групи і 27,7 \% студентів експериментальної групи.

Отримані дані свідчать про те, що застосування словників різних типів під час виконання завдань з іноземної мови не завжди уможливлює надання правильних повних відповідей, i, як наслідок, перешкоджає отриманню якісних знань з іноземної мови. Для якісного виконання роботи зі словником потрібно наполегливо впроваджувати в навчальний процес словникові технології, під якими ми розуміємо не тільки доступ студентів до найновіших словникових видань, але й озброєння їх глибоким знанням самого словника і мистецтвом ним користуватися.

Наступним завданням констатувального етапу експериментальної роботи було виявлення рівня пізнавальної активності студентів у процесі роботи зі словником, зростання якої тісно пов'язане із категоріями систематичності і послідовності роботи студентів зі словником. Систематичне використання словника в процесі набуття нових знань уможливить підвищення якості знань студента, формування нових умінь і навичок, появу самостійних поглядів, створить передумови для розвитку його особистісних якостей, надасть можливість розширити зміст знань і швидше зумовить професійне самовдосконалення.

Узагальнені результати дослідження сформованості рівнів пізнавальної активності студентів у процесі роботи зі словниками подано в табл. 3.

Рівні розвитку активності студентів у процесі роботи зі словником

Таблиия 3

\begin{tabular}{|c|c|c|}
\hline \multirow{2}{*}{ Рівні } & \multicolumn{2}{|c|}{ Студенти (\%) } \\
\cline { 2 - 3 } & Контрольна група & Експеримент. група \\
\hline високий & 16,9 & 17,9 \\
\hline середній & 35,1 & 34,6 \\
\hline низький & 48 & 47,5 \\
\hline
\end{tabular}

На основі аналізу таблиці 3 можна зробити висновок, що високий рівень активності у процесі роботи зі словником має лише 16,9 \% студентів контрольної і 17,9 \% студентів експериментальної групи. Для більшості студентів контрольної й експериментальної 
групи характерний середній і низький рівень активності. Ці дані свідчать про те, що з боку викладачів не приділяється достатньо уваги розвитку пізнавальної активності студентів під час роботи зі словником.

Важливе значення для активізації навчально-пізнавальної діяльності студентів у процесі роботи зі словниками має такий критерій, як самостійність.

Самостійність передбачає оволодіння знаннями, вміннями і навичками як компонентами змісту освіти, логічної роботи із запропонованим матеріалом та наявність мотиваційної настанови. Вона означає оволодіння прийомами раціональної діяльності після самостійного здобуття знань, їх ефективного засвоєння й перероблення [1].

Результати дослідження щодо виявлення наявного рівня пізнавальної самостійності студентів у процесі виконання різних видів робіт зі словником на заняттях і під час самостійної роботи подано в діаграмі (див. рис. 2).

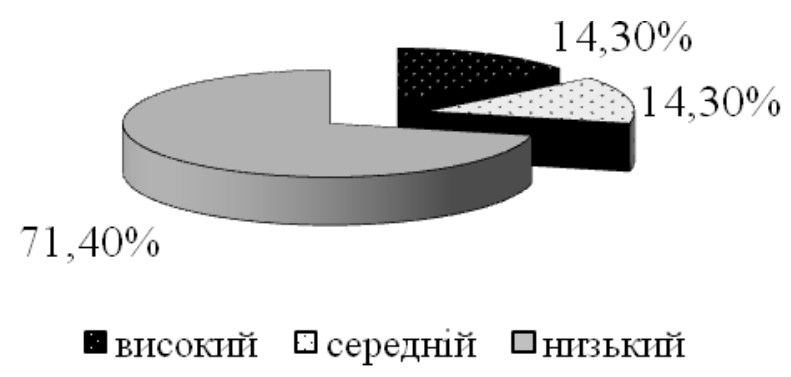

Рис. 2. Рівні розвитку самостійності студентів у процесі роботи зі словником

На основі аналізу даних, поданих у діаграмі, можна зробити висновок, що у студентів недостатньо сформована самостійність у процесі роботи зі словником, що зумовлено низькою мотивацією навчання іноземних мов, низьким рівнем сформованості вмінь і навичок роботи зі словником, а також недостатнім розвитком активності під час користування словником.

Оскільки ми розглядаємо в дослідженні словник як засіб розвитку особистості, оволодіння іноземною мовою й отримання фахових знань зі спеціальності на рівні вивчення професійно орієнтованої іноземної мови, необхідно, щоб студент володів належним рівнем користування словником.

Результати самооцінки студентами свого рівня володіння словником показали такий розподіл студентів за рівнями розвитку готовності до використання словника для самоосвіти (табл. 4).

Таблиия 4

Рівні розвитку готовності студентів до самоосвіти

\begin{tabular}{|c|c|c|}
\hline \multirow{2}{*}{ Рівні } & \multicolumn{2}{|c|}{ Студенти (\%) } \\
\cline { 2 - 3 } & Контрольна група & Експеримент. Група \\
\hline високий & 2,5 & 2.7 \\
\hline середній & 82 & 82,2 \\
\hline низький & 15.5 & 15,1 \\
\hline
\end{tabular}

Результати дослідження надають змогу стверджувати, що у студентів переважає середній і низький рівень готовності до використання словників для здобуття глибоких і міцних знань у процесі подальшої самоосвіти.

Сучасний ринок праці висуває високі вимоги до якості знань і рівня підготовки фахівців, які повинні постійно удосконалювати свою професійну майстерність, самостійно оволодіваючи науково-практичною інформацією, пов'язаною 3 фахом, «оскільки уміння спілкуватися мовою професії підвищує ефективність праці, допомагає краще орієнтуватися не тільки на виробництві, а й у безпосередніх ділових контактах із колегами» [5]. 
Здійснюючи констатувальний експеримент, ми досліджували, як студенти немовних спеціальностей розуміють можливості словників різних типів (особливо галузевих) у формуванні професійних знань.

За показниками використання студентами словників тих чи інших типів ми визначили рівень розвитку готовності студентів до використання словників у професійній діяльності. Результати дослідження наведено в табл. 5.

Рівні розвитку готовності студентів до професійної діяльності

Таблиия 5

\begin{tabular}{|c|c|c|}
\hline \multirow{2}{*}{ Рівні } & \multicolumn{2}{|c|}{ Студенти (\%) } \\
\cline { 2 - 3 } & Контрольна група & Експеримент. група \\
\hline високий & 3,5 & 3,8 \\
\hline середній & 12,1 & 11,1 \\
\hline низький & 84,4 & 85,1 \\
\hline
\end{tabular}

Аналіз таблиці свідчить, що готовність студентів до професійної діяльності з використанням галузевих словників сформована недостатньо. Для більшості студентів характерний низький і середній рівень. Високий рівень мають 3,5\% студентів контрольної і $3,8 \%$ студентів експериментальної груп.

Узагальнюючи, зазначимо, що за всіма критеріями активізації навчально-пізнавальної діяльності у процесі роботи зі словниками переважає низький та середній рівень. Причини такого стану слід шукати не тільки в соціальних умовах, пов'язаних 3 високою ціною словників, але й у самій системі навчання іноземних мов, що характеризується фрагментарним використанням словників.

Під час діагностування критеріїв активізації навчально-пізнавальної діяльності студентів у процесі роботи зі словниками підтвердилось припущення про те, що ефективність навчальнопізнавальної діяльності під час навчання іноземних мов визначається ступенем залучення словників у навчальний процес.

Перспективи подальших досліджень полягають у визначенні рівнів критеріїв активізації навчально-пізнавальної діяльності студентів немовних спеціальностей у процесі роботи зі словниками після проведення експериментального навчання за дослідною моделлю.

\section{Література}

1. Єгорова Е. Б. Мотивація професійного вибору школярів / Е. Б. Єгорова // Проблеми освіти: [наук.-метод. зб.]. - К. : ІСДО. - 1998. - № 11. - С.114-115. 2. Китайгородская Г. А. Методические основы интенсивного обучения иностранным языкам / Г. А. Китайгородская. - М. : Изд-во Моск.ун-та, 1986. - 100 с. З. Максименко С. Д. Загальна психологія: [навч. посіб.] / С. Д. Максименко, В. О. Соловієнко. - К. : МАУП, 2000. - 256c. 4. Програма $з$ англійської мови для університетів/інститутів (п'ятирічний курс навчання): Проект / колектив авторів: С. Ю. Ніколаєва, М. І. Соловей, Ю.В.Головач. - Вінниця : Нова книга, 2001. - 246с. 5. Бондаренко Г. П. Професійна термінологія як засіб формування мовленнєвої компетенції майбутнього фахівця [Електронний ресурс]. / Г. П. Бондаренко :- Режим доступу: http://www.bdpu.org 